\title{
Een rijk geschakeerd palet
}

De professionele autonomie van de arts in diens klinisch werk, of juist de mogelijke aantasting daarvan, heeft de Nederlandse gemoederen flink bezig gehouden. Hoe onafhankelijk mogen en moeten wetenschappers en artsen zijn als het gaat om het nemen van beslissingen over het welzijn van patiënten? Het kabinet Balkenende IV wist een dreigende breuk in de coalitie hierover tijdig te voorkomen nadat staatssecretaris Bussemaker goedbedoeld het Academisch Ziekenhuis Maastricht de hand boven het hoofd had gehouden bij de selectie van embryo's in geval van erfelijke borst- en ovariumkanker. Zij werd prompt teruggefloten door haar christelijke coalitiegenoten. Het TMO-nummer dat u nu onder ogen heeft, werpt een blik op de professionele autonomie van artsen. De actieve groep studenten geneeskunde die het KNMG Studentenplatform vormen - zijnde een landelijke en onafhankelijke belangenbehartiger van studenten geneeskunde in Nederland - toont aan dat een meerderheid van de door hen bevraagde aankomende artsen deze autonomie een absolute voorwaarde noemt voor het adequaat kunnen uitoefenen van het artsenberoep. Opvallende nuancering was dat de mannelijke ondervraagden de vraag hierover significant vaker beaamden dan hun vrouwelijke collega's. Het gaat bij professionele autonomie om “...vrijheid van oordeelsvorming van de arts om (...) zonder inmenging van derden (...) te komen tot diagnosestelling en advisering over behandeling en/of (...) interventies, waarbij inbegrepen het onderzoeken, het geven van raad met als doel de bescherming en/of verbetering van de gezondheidstoestand van de patiënt." Voorwaar een uitgangspunt dat overeenstemt met de gedegen en brede opleiding die afstuderende artsen in Nederland en Vlaanderen hebben doorlopen, en met de beroepsmatige verantwoordelijkheid die van oudsher bij het beroep hoort. Een ongelukkige bijkomstigheid bij de periodieke enquêtes vanuit dit KNMG Studentenplatform is het lage responspercentage. Volgens de statistieken waren ten tijde van het onderzoek 17.112 studenten in opleiding tot arts in Nederland, van wie er 6.216 KNMG studentlid waren. Aan deze laatste groep is een enquête gestuurd die door $32,5 \%$ werd ingevuld. Maar, afgezet tegen het totaal aantal studerenden komt de respons uit op $11,6 \%$, waarbij ik dan even voorbijga aan een mogelijke selectiebias ten gevolge van het KNMG-lidmaatschap. De lage responspercentages doen de vraag rijzen in hoeverre resultaten verkregen uit deze enquêtes generaliseerbaar zijn. Maar, de onderzoekers hebben wellicht gedacht: 'als het niet kan zoals het moet, dan moet het maar zoals het kan', en de bevindingen van hun onderzoek zouden in elk geval voor het kabinet aanleiding moeten zijn uiterste terughoudendheid te betrachten voordat zij achter de deur van de spreekkamer willen meebeslissen over wat medisch gezien wel en niet wenselijk is voor individuele patiënten.

Wat kunt u nog meer verwachten in dit nummer? Dat mannen en vrouwen aanzienlijk verschillen in appreciatie van de beroepskenmerken van artsen. Radema- 
kers en haar collega's komen tot opmerkelijke resultaten die wellicht de gangbare stereotypieën rondom vrouwelijke en mannelijke artsen bevestigen, maar ook opnieuw aantonen dat in de klinische fase een vermindering in 'care'-gerichtheid ontstaat en dat dit met name bij vrouwen het geval is. Komt dat doordat de rolmodellen in die fase nog voornamelijk van het mannelijk geslacht zijn en deze als zodanig een masculinisering teweegbrengen? Of gaat het in de klinische fase van de opleiding om de 'harde feiten' waar je als aankomend arts op wordt afgerekend, en niet zozeer om de meer humanitaire aspecten van de beroepsuitoefening? Vermeld moet worden dat de gegevens waarop de auteurs zich baseren dateren van zes jaar geleden. Hopelijk kunnen we spoedig een meer actuele stand van zaken van deze verschuivingen tegemoet zien. Immers, met de huidige toegenomen aandacht voor de persoonlijke ontwikkeling van studenten geneeskunde, wordt niet alleen de vraag relevant welke gevolgen individuele veranderingen met zich meebrengen, maar ook wat er in de opleidingen kan en moet worden gedaan om ongewenste en/of ongewilde veranderingen in beroepshouding voor te zijn of bij te sturen.

En waar zul je dan je verbeteringen zeker ook willen aanbrengen, mede in het licht van het competentiegerichte leren dat niet onopgemerkt zijn intrede heeft gedaan? Bij de vervolgopleidingen die de aankomende generatie opleiders gaat klaarstomen voor de komende decennia. In Noord-Oost Nederland weten ze in dit verband wel van aanpakken. Met de Kindergeneeskunde en Obstetrie \& Gynaecologie als speerpunten beschrijven Jippes et al. de invoering van hun vernieuwde specialistenopleiding inclusief docentprofessionalisering, portfolio's en E-learning. Hopelijk wordt in al deze vernieuwings- drang de individuele arts in opleiding tot specialist en diens persoonlijke groei en ontwikkeling niet uit het oog verloren. Terecht merken de auteurs op dat grondige wijzigingen gemakkelijk op weerstand kunnen stuiten, en dat succesvolle implementatie staat of valt bij het enthousiasme van de professionals op de werkvloer.

Wat voor wensenlijstjes bestaan er nog meer? In een eerder redactioneel is al eens de invoering van onderwijs in de humanities bepleit, in het voorliggende TMO wordt door huisarts Van Dijk en zijn collega's een lans gebroken voor het gestructureerd aandacht besteden aan complementaire geneeswijzen in de basisopleiding. Binnen de opleidingen aan vrijwel alle Nederlandse faculteiten wordt dit onderwerp aan de orde gesteld, hetzij in keuzeonderwijs, hetzij in een meer verplichtende vorm, met een omvang die varieert van één college tot vier weken full time. Daarmee loopt Nederland in de pas met de Verenigde Staten en Canada, en zelfs voor op andere landen uit de Europese Unie. Desalniettemin pleiten de schrijvers voor het honoreren van de wens van vele patiënten dat artsen tenminste een goed advies kunnen geven bij hun zoektocht naar eventuele behandeling en genezing met acupunctuur, homeopathie of alternatieve geneeswijzen. Het ligt voor de hand aanstaande artsen tenminste op de hoogte te brengen van hetgeen op dit gebied in Nederland 'te koop' is, al was het maar om voor henzelf te kunnen nagaan in hoeverre zij binnen de genoemde mogelijkheden het kaf van het koren kunnen scheiden en patiënten waar mogelijk steun kunnen bieden en kunnen beschermen tegen kwakzalverij. Zo kunnen artsen professioneel autonoom blijven en vanuit hun eigen kennis en kunde hun patiënten optimaal adviseren.

Een referaat van Custers betreft recente studies van Woods et al. naar rol en func- 
tie van de basisvakken (de biomedische kennis) voor het correct diagnosticeren van ziekten. Het ligt genuanceerd, zo laat Custers zien aan de hand van enkele wetenschappelijke studies over de mogelijk indirecte rol die de basisvakken spelen. De conclusie van de onderzoekers dat eenvoudige causale verbanden tussen klinische verschijnselen voldoende zijn voor studenten om bepaalde ziekten en symptomen met elkaar in verband te brengen wordt kritisch onder de loep genomen. Het referaat vecht conclusies aan, maar is wellicht vooral een stimulans voor onze lezers om zelf de bronnen te bestuderen en gefascineerd te worden door empirisch wetenschappelijk onderzoek op dit gebied.

Ten slotte wordt in onze speciale rubriek de aandacht gericht op het kind in de schilderkunst, niet alleen qua verschijningsvorm, emotie, innerlijk - vaak zo fraai uitgebeeld - maar ook op het treffend weergeven wat ziekte met een kind doet. De redactie hoopt $\mathrm{u}$ met dit TMO-nummer opnieuw een rijk geschakeerd palet aan te bieden!

Benno Bonke 